\title{
Knowledge Economy and its Effect on Permanent Human Development, Youth and Sports Directorate in Alexandria
}

\author{
Assistant Prof. / Dr. / NADIA LOTFY ABDELFATTAH
}

Assistant Professor, Department of Sports Administration, Faculty of Physical Education for Girls - Alexandria University

\section{Research Introduction and Problem}

In agreement with strategic view included under document of Egypt for permanent development, an individual factor about Egypt's view of knowledge, invention and scientific research made by the Egyptian government in (2015) that Egypt shall, by (2030) be a creative community producing science, technology and knowledge characterized by an integrated system including the development value of human invention and knowledge, as knowledge applications and invention outcomes are related to development objectives and challenges.

Accordingly, average of creating and promoting knowledge is increasing due to rapid advancement in information and communication technology whose prices reduced considerably specially costs of computerizing, and electronic network in addition to producing economic changes resulted in different economic powers trying to push international economy towards its objectives and interests, also it resulted in the so called globalization. (21:2)

Knowledge becomes a marketable product and if it is used perfectly it may affect much information and advanced technology creating an additional value and a greater growth to result in directing to knowledge economy. (35:16)

Knowledge is to use techniques to improve life quantity in all fields and activities by using information, internet and different information applications and achieving profits in relevant productivity. (44) (31:87)

Reda Ibrahim et al (2010) agree with Medhat Abo Elnasr (2008) that there are knowledge characteristics, human, integrated, changeable, accumulated and rapid adaptable process and affects behavior and establishment availing required knowledge needs through data, information and infrastructure. (35:76) $(27: 127)$

Also it is the corner stone of development as reusing generated and new knowledge may reduce cost and accelerate offering products in market early achieving returns then penetrating market to achieve a longer competitive advantage for the project. (34:242)

Now, it is expected for knowledge and technology applications to the most striking power feature with transfer we witness at the knowledge beginning, after military power was the final, then economic power prevailed in industry 
age and knowledge power is mastering now in the age of technology know as knowledge economy. (29)

Results of study of Mohamed Saied Gomaa (2009) (24) confirmed the importance of knowledge economy which increased through the considerable role confirmed by knowledge in identifying economy nature and activity, identifying methods and techniques used in these activities and in needs and services met and provided by Knowledge economy is this branch of economy focusing on achieving general welfare and service towards development depending on scientific research and incorporated under strategic objectives for which work continues to achieve a permanent and integrated development. $(6: 13)$

Results of study of Abdel Motelb Abdel Hamid (2011) defines as economy of acquiring, using and inventing knowledge to improve life quality with its different fields, using human mind and scientific research to create some strategic changes in the economic setting nature and organizing the same to attend challenges of globalization, information technology, communication and knowledge internationality. (4:84)

Knowledge economy is characterized by some characteristics including (globalization, adaptation with customers' desires, rare human cadres and skills, focusing on consumer's services, e-commerce, permanent education need). (12)

Knowledge is the corner stone of permanent human development as it is a tool or expanding human choices and abilities to enable them to overcome financial deprivation and building prosperous communities, also knowledge, in terms of production and use and at the beginning of the $21^{\text {st }}$ century became the method of achieving a permanent human development in all fields. (17:11)

Accordingly the relationship between human development and permanent development concept received a great concern, as this relationship appears through the dire need of finding a balance between population from one side and available sources from the other side, accordingly it is a present - future relationship to secure better life and standard of living for the next generations which may need linking environmental issues to development certainly and permanently as no permanent development without human development. (22)

Also results of study of Saad Khodir Abbas El Rahimi (2005) (37) confirm that knowledge for communities aiming at achieving integrated development is a final issue and information technology and communication's represent main tools of achieving organizational advancement on knowledge economy towards real conversion by using natural and financial resources. 
Human development has 2 aspects: First: for building human capacities to improve health level, knowledge and skills and second: people's profit from spare time and for production and activity in the field of culture, humanity and policy, accordingly income is nothing but one option and that national product increase is a main condition of human development but not enough. (28: 178)

Saied Bu Zed (2013) (39) found five main indicators for permanent human development under Orthodox role, empowerment, the ability of taking a part in the organizations decisions, cooperation including intimacy and combination as a main source of individual's self satisfaction, equity including equal capacities and opportunities and security.

Developmental united nations program focusing on main and important objectives of permanent human development including getting rid of poverty, creating jobs, permanent means of living and environment protection and renewal, all these objectives depend on education development and developing knowledge and technical capacities of individuals. (44)

Results of study of Mohamed Khodiry (2004) (26) confirms the clear effect of knowledge economy in achieving the latent competitive capacity through focusing on creating inventive capacity and preparing the inventive capacity, human capital and technology infrastructure.

Also results of Study of Ahmed Abdall El Zaybat (2007) (5) prove characteristics must be enjoyed by human resource in knowledge economic age which form important sufficiency including creative thinking and flexibility in science, learning, permanent training, self learning and ability to use information technology and communications.

Results of study of Walter Paula, Kissa Sinlzn (2004) (41) that the main component of knowledge economy is the increasing dependence on ideology capacities of focusing on financial inputs and natural resources.

Results of study of Dian Gabriel Trimplay (2003) (13) that competitive advantage of some organizations depends on adopting and applying information and communications and multi media.

The researcher believe that this subject for some organizations offering sports services and activities including youth and sports directorates, we will find a different affair and till now they have not tried to update themselves, attend this age developments and depending on technology, although they are the bases of applying knowledge economy as a main factor of human development on the long run or the so called: permanent human development. 
This what was confirmed by some studies results such as results of study of Khaled El Mahdy El Nagem Mohamed (2012) (21) whose results are techniques play a main role in economic development, as focusing on developing human resources is a strategic perspective including permanent scientific and technical creation aiming at providing new products (goods or services), study of Saa'd Mohamed (2016) (38) that confirmed that human development term became the education role in development and transferring to the so called knowledge economy that depended on information technology and communication.

Study of Hussein Ahmed Dakhil El Sarhan (without) (18) that there is a mutual relationship between knowledge development, education promotion, human capacities and skills expansion and creating a real permanent human development.

Study of Marwa Fargly Gaber (2015) (30) that recommended the importance of a knowledge department, faculty of Physical education for girls due to its importance for increasing knowledge economy.

Accordingly the researcher discussed the subject titled:

\section{Knowledge Economy and its Effect on Permanent Human Development, Youth and Sports Directorate in Alexandria}

\section{Research Objectives:}

The research aims at studying knowledge economy and its effect on achieving permanent human development in youth and sports directorate, Alexandria through identifying:

1. Knowledge economy dimensions in youth and sports directorates.

2. Permanent human development indicators in youth and sports directorate.

3. The relationship between cognitive economy and permanent human development.

\section{Research Hypothesis:}

Is there any statistical significance relationship between knowledge economy and permanent human development in youth and sports directorate?

\section{Research Procedures:}

Research Method: Survey descriptive method was used as suitable for the research nature.

\section{Research Community:}

Research community was selected from youth and sports directorate, Alexandria governorate totaling (83) subjects selected by inclusive determination as the table shows the same 
Table (1)

Numerical description of the study sample distributed to pilot and main studies

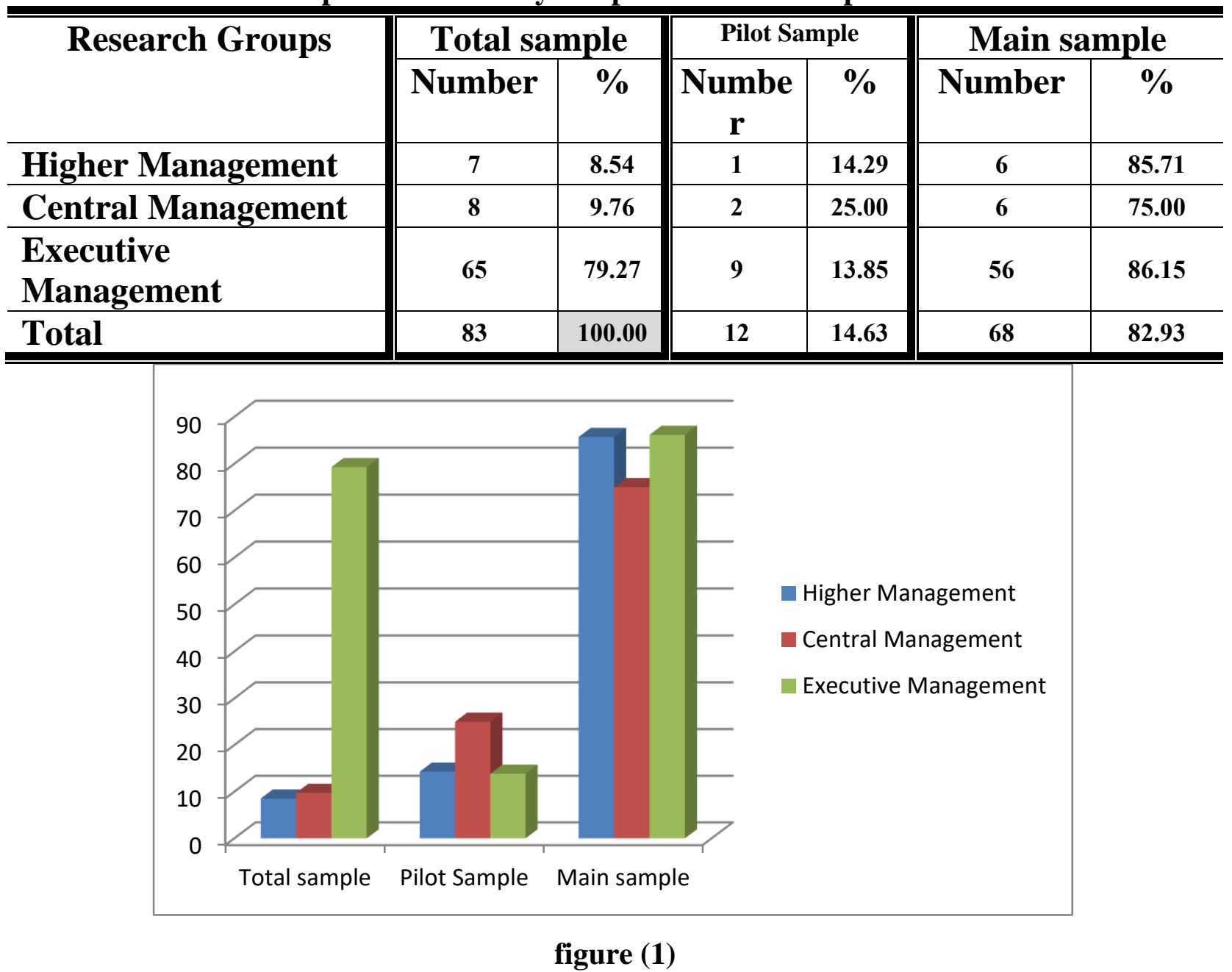

Numerical description of the study sample distributed to pilot and main studies

Data Collection Tools: The researchers used questionnaire form to collect data

\section{Questionnaire Form Scientific Coefficient:}

\section{First: Form Validity:}

To reach form validity, the researchers depended on:

\section{- Internal Consistency Validity}

Table number (2) internal consistency coefficient (coefficient of the phrase correlation with the grand total of its dimension)

\section{Scientific Coefficient of Questionnaire Form:}
A. Internal consistency validity

Table (2)

The agreement of the experts on the terms and axes of the questionnaire form

$$
\mathbf{n}=\mathbf{9}
$$




\begin{tabular}{|c|c|c|c|c|c|c|c|c|c|c|c|}
\hline \multicolumn{3}{|c|}{ The first axis } & \multicolumn{3}{|c|}{ The first axis } & \multicolumn{3}{|c|}{ The second axis } & \multicolumn{3}{|c|}{ The second axis } \\
\hline $\begin{array}{c}\text { No. } \\
\text { phrase }\end{array}$ & $\mathbf{R}$ & $\%$ & $\begin{array}{c}\text { No. } \\
\text { phras } \\
\text { e }\end{array}$ & $\mathbf{R}$ & $\%$ & $\begin{array}{c}\text { No. } \\
\text { phrase }\end{array}$ & $\mathbf{R}$ & $\%$ & $\begin{array}{c}\text { No. } \\
\text { phrase }\end{array}$ & $\mathbf{R}$ & $\%$ \\
\hline \multicolumn{3}{|c|}{ The first dimension } & \multicolumn{3}{|c|}{ third dimension } & \multicolumn{3}{|c|}{ The first dimension } & \multicolumn{3}{|c|}{ Second dimension } \\
\hline 1 & & & 14 & 8 & 88.8 & 1 & & & 4 & 8 & 88.8 \\
\hline $1 / 1$ & 8 & 88.8 & 15 & 8 & 88.8 & $1 / 1$ & 9 & 100 & $4 / 1$ & 9 & 100 \\
\hline $1 / 2$ & & & 16 & 9 & 100 & $1 / 2$ & 7 & 7.77 & $4 / 2$ & 8 & 88.8 \\
\hline $1 / 3$ & 9 & 100 & 17 & 8 & 88.8 & $1 / 3$ & 8 & 88.8 & $4 / 3$ & 9 & 100 \\
\hline $1 / 4$ & 8 & 88.8 & 18 & 9 & 100 & $1 / 4$ & 9 & 100 & $4 / 4$ & 9 & 100 \\
\hline $1 / 5$ & 9 & 100 & 19 & 8 & 88.8 & $1 / 5$ & 8 & 88.8 & $4 / 5$ & 9 & 100 \\
\hline 2 & & & 20 & 8 & $\begin{array}{l}88.8 \\
\end{array}$ & $1 / 6$ & 8 & 88.8 & 5 & & \\
\hline 3 & 7 & 7.77 & 21 & 9 & 100 & $1 / 7$ & 9 & 100 & $5 / 1$ & 8 & 88.8 \\
\hline 4 & 8 & 88.8 & 22 & 8 & 88.8 & 2 & 9 & 100 & $5 / 2$ & 8 & 88.8 \\
\hline $1 / 4$ & 9 & 100 & 23 & 9 & 100 & 3 & & & $5 / 3$ & 9 & 100 \\
\hline $2 / 4$ & 8 & 88.8 & 24 & & & $3 / 1$ & & & $5 / 4$ & 9 & 100 \\
\hline 5 & & & $24 / 1$ & 9 & 100 & $3 / 1 / 1$ & 9 & 100 & $5 / 5$ & 8 & 88.8 \\
\hline $5 / 1$ & 9 & 100 & $24 / 2$ & 8 & $\begin{array}{l}88.8 \\
\end{array}$ & $3 / 1 / 2$ & 8 & 88.8 & $5 / 6$ & 9 & 100 \\
\hline $5 / 2$ & 8 & 88.8 & 25 & & & $3 / 1 / 3$ & 8 & 88.8 & $5 / 7$ & 9 & 100 \\
\hline $5 / 3$ & 9 & 100 & $25 / 1$ & 7 & 7.77 & $3 / 1 / 4$ & 9 & 100 & $5 / 8$ & 8 & 88.8 \\
\hline $5 / 4$ & 8 & 88.8 & $25 / 2$ & 8 & 88.8 & $3 / 1 / 5$ & 9 & 100 & \multicolumn{3}{|c|}{ third dimension } \\
\hline 6 & 9 & 100 & $25 / 3$ & 7 & 7.77 & $3 / 1 / 6$ & 9 & 100 & 6 & 9 & 100 \\
\hline \multicolumn{3}{|c|}{ Second dimension } & $25 / 4$ & 9 & 100 & $3 / 1 / 7$ & 8 & 88.8 & 7 & 8 & 88.8 \\
\hline 7 & & & $5 / 25$ & 8 & 88.8 & $3 / 1 / 8$ & 8 & 88.8 & $7 / 1$ & 8 & 88.8 \\
\hline $7 / 1$ & 9 & 100 & $25 / 6$ & 9 & 100 & $3 / 1 / 9$ & 9 & 100 & $7 / 2$ & 9 & 100 \\
\hline $7 / 2$ & 7 & 7.77 & & & & $3 / 1 / 10$ & 8 & 88.8 & $7 / 3$ & 7 & 7.77 \\
\hline $7 / 3$ & 9 & 100 & & & & $3 / 2$ & & & 8 & 8 & 88.8 \\
\hline $7 / 4$ & 9 & 100 & & & & $3 / 2 / 1$ & 8 & 88.8 & 9 & 9 & 100 \\
\hline 8 & 8 & 88.8 & & & & $3 / 2 / 2$ & 9 & 100 & 10 & 8 & 88.8 \\
\hline 9 & 8 & 88.8 & & & & $3 / 2 / 3$ & 9 & 100 & 11 & 9 & 100 \\
\hline 10 & 7 & 7.77 & & & & $3 / 2 / 4$ & 8 & 100 & 12 & 8 & 88.8 \\
\hline 11 & 9 & 100 & & & & $3 / 2 / 5$ & 9 & 100 & \multicolumn{3}{|c|}{ The fourth dimension } \\
\hline 12 & 8 & 88.8 & & & & $3 / 2 / 6$ & 9 & 100 & 13 & 9 & 100 \\
\hline 13 & & & & & & & & & 14 & 8 & 88.8 \\
\hline 13/1 & 8 & 88.8 & & & & & & & 15 & 9 & 100 \\
\hline $13 / 2$ & 8 & 88.8 & & & & & & & 16 & & \\
\hline \multirow[t]{4}{*}{$13 / 3$} & 7 & 7.77 & & & & & & & $16 / 1$ & 9 & 100 \\
\hline & & & & & & & & & $16 / 2$ & 9 & 100 \\
\hline & & & & & & & & & $16 / 3$ & 9 & 100 \\
\hline & & & & & & & & & $16 / 4$ & 8 & 88.8 \\
\hline
\end{tabular}

It is clear from Table (2) of the frequency and percentage of the agreement of experts on the questionnaire questionnaire that the percentage of agreement ranged from $77.7 \%$ to $100 \%$. Therefore, the researcher relied on all the statements due to achieving $75 \%$ or more according to the opinions of the experts. 
Table (3)

Statements amended, combined and added in questionnaire form upon experts opinion

\begin{tabular}{|c|c|c|c|c|c|}
\hline \multirow[t]{2}{*}{ Factors } & \multicolumn{3}{|c|}{ Redrafting } & \multirow{2}{*}{$\begin{array}{c}\text { Statements } \\
\text { Combination }\end{array}$} & \multirow{2}{*}{$\begin{array}{c}\text { Adding } \\
\text { Statements }\end{array}$} \\
\hline & Statement No. & Before amend & After amend & & \\
\hline \multirow[t]{4}{*}{$\begin{array}{l}\text { First } \\
\text { Factor }\end{array}$} & \multirow[t]{2}{*}{$\begin{array}{c}\text { First } \\
\text { Dimension }\end{array}$} & $\begin{array}{l}2.1 \text { Redrafting } \\
\text { and reformation }\end{array}$ & $\begin{array}{l}\text { 2.1 Permanent Re- } \\
\text { modification }\end{array}$ & & 7 \\
\hline & & $\begin{array}{l}\text { 5.4 Manpower } \\
\text { field }\end{array}$ & $\begin{array}{c}5.4 \text { Bio-field for } \\
\text { attracting, selecting } \\
\text { and appointing } \\
\text { employees }\end{array}$ & & \\
\hline & \multirow{2}{*}{$\begin{array}{c}\text { Third } \\
\text { Dimension }\end{array}$} & \multirow{2}{*}{$\begin{array}{l}25.1 \text { Attendance } \\
\text { and absence }\end{array}$} & \multirow{2}{*}{$\begin{array}{c}27.1 \text { Observing } \\
\text { official work times }\end{array}$} & & 18 \\
\hline & & & & & 25 \\
\hline \multirow[t]{3}{*}{$\begin{array}{l}\text { Second } \\
\text { Factor }\end{array}$} & \multirow[t]{3}{*}{$\begin{array}{c}\text { First } \\
\text { Dimension }\end{array}$} & $\begin{array}{l}1.5 \text { Authorizing } \\
\text { power in case of } \\
\text { his superior } \\
\text { absence }\end{array}$ & $\begin{array}{c}\text { 1.5 Confirming } \\
\text { power } \\
\text { authorization }\end{array}$ & & \multirow[t]{3}{*}{$3 / 2 / 7$} \\
\hline & & $\begin{array}{l}\text { 3/1/5 Keeping } \\
\text { and adhering to } \\
\text { employee in his / } \\
\text { her work }\end{array}$ & $\begin{array}{l}\text { 3/1/5 Achieving } \\
\text { occupational safety }\end{array}$ & $1 / 2-1 / 6$ & \\
\hline & & $\begin{array}{l}\text { 3/1/8 High } \\
\text { individuals } \\
\text { resistance to } \\
\text { work pressures }\end{array}$ & $\begin{array}{l}\text { 3/1/8 Work } \\
\text { pressure resistance }\end{array}$ & & \\
\hline
\end{tabular}

After these amends, the questionnaire form took its final form, attachment number (3) and included (28) main statements and (79) marginal statements, also all experts agreed upon the suggested estimation balance at ( $100 \%)$. 


\section{B - The honesty of differentiation:}

Table (4)

Peripheral comparison between the upper quadrants and the lower quadrants in the "first axis: the dimensions of the knowledge economy and the second axis the indicators of sustainable human development and the axes complex" of the research sample to find the truth coefficient

\begin{tabular}{|c|c|c|c|c|c|c|c|}
\hline \multirow[b]{2}{*}{ Variables } & \multicolumn{2}{|c|}{$\begin{array}{c}\text { Top quarters } \\
\quad \mathbf{n}=\mathbf{3}\end{array}$} & \multicolumn{2}{|c|}{$\begin{array}{l}\text { Lower quadrants } \\
\qquad \mathbf{n}=\mathbf{3}\end{array}$} & \multirow{2}{*}{$\begin{array}{c}\text { The } \\
\text { difference } \\
\text { Among the } \\
\text { average }\end{array}$} & \multirow{2}{*}{$\begin{array}{l}\text { Value } \\
\text { (T) }\end{array}$} & \multirow{2}{*}{$\begin{array}{l}\text { Honesty } \\
\text { coefficien }\end{array}$} \\
\hline & Arithmetic mean & standard deviation & $\begin{array}{c}\text { Arithmetic } \\
\text { mean }\end{array}$ & $\begin{array}{l}\text { standard } \\
\text { deviation }\end{array}$ & & & \\
\hline $\begin{array}{l}\text { First Dimension: Human } \\
\text { Development and Invention }\end{array}$ & 12.67 & 0.58 & 7.00 & 1.00 & 5.67 & $* 8.50$ & 0.97 \\
\hline $\begin{array}{c}\text { Second Dimension: } \\
\text { Infrastructure depending on } \\
\text { information technology and } \\
\text { communication } \\
\end{array}$ & 6.00 & 1.00 & 2.33 & 0.58 & 3.67 & $* 5.50$ & 0.94 \\
\hline $\begin{array}{l}\text { Third Dimension: Orthodox } \\
\text { Organizational Control }\end{array}$ & 14.00 & 1.00 & 8.00 & 1.00 & 6.00 & $* 7.35$ & 0.96 \\
\hline $\begin{array}{l}\text { the First Factor: Knowledge } \\
\text { Economy Dimensions }\end{array}$ & 32.67 & 2.52 & 17.33 & 2.52 & 15.33 & $* 7.46$ & 0.97 \\
\hline (First Dimension: Enablement) & 10.00 & 1.00 & 6.33 & 0.58 & 3.67 & $* 5.50$ & 0.94 \\
\hline $\begin{array}{l}\text { Second Dimension: } \\
\text { Occupational Safety }\end{array}$ & 5.67 & 1.15 & 2.00 & 1.00 & 3.67 & $* 4.16$ & 0.90 \\
\hline $\begin{array}{l}\text { Third Dimension: Justice and } \\
\text { Equity }\end{array}$ & 4.33 & 0.58 & 1.33 & 0.58 & 3.00 & *6.36 & 0.95 \\
\hline $\begin{array}{c}\text { Fourth Dimension: } \\
\text { Cooperation Fourth } \\
\text { Dimension: Cooperation }\end{array}$ & 7.00 & 0.00 & 3.33 & 1.15 & 3.67 & $* 5.50$ & 0.94 \\
\hline $\begin{array}{l}\text { The Second Factor Results: } \\
\text { Permanent Human } \\
\text { Development Indicators }\end{array}$ & 27.00 & 2.65 & 13.00 & 3.00 & 14.00 & $* 6.06$ & 0.95 \\
\hline $\begin{array}{c}\text { The questionnaire as a whole } \\
\text { axes }\end{array}$ & 59.67 & 5.03 & 30.33 & 5.51 & 29.33 & $* 6.81$ & 0.96 \\
\hline
\end{tabular}

\section{* Significant at $0.05=2.78$}

From Table (4) of differences between higher and lower quarters in the first factor: knowledge economy dimensions (human development and invention - technology infrastructure - Orthodox organizational control), the second factor: permanent human development indicators and total questionnaire to find validity coefficient, there are statistical significant differences between the two groups as $(\mathrm{T})$ calculated value was greater than $(\mathrm{T})$ tabular value at level $(0.05)=(2.78)$, also validity coefficient value ranged between $(0.94$ to $0.97)$ for the first factor, between $(0.90$ to 0.95$)$ for the second factor and total questionnaire (0.96) to confirm that the researched questionnaire measured what was made for and can distinguish between different levels. 


\section{Discussing Results}

Discussing the First Factor Results: Knowledge Economy Dimensions (Human Development and Invention Technology Infrastructure - Orthodox Organizational Control)

Table (5)

Repetition, Percentage and $\mathrm{K}^{2}$ for the Three Administrative Levels of the First Factor: Knowledge Economy Dimensions

\begin{tabular}{|c|c|c|c|c|c|c|c|c|}
\hline \multirow[b]{2}{*}{$\mathrm{S}$} & \multirow[b]{2}{*}{ Statements } & \multicolumn{2}{|c|}{$\begin{array}{c}\text { Executive Management } \\
\mathrm{N}=56 \\
\end{array}$} & \multicolumn{2}{|c|}{$\begin{array}{c}\text { Central Administration } \\
\mathrm{N}=6 \\
\end{array}$} & \multicolumn{2}{|c|}{$\begin{array}{c}\text { Senior Management } \\
\mathrm{N}=6 \\
\end{array}$} & \multirow{2}{*}{$\begin{array}{c}\text { Crosal } \\
\text { Wallis } \\
\text { Test } \\
\text { "K2" }\end{array}$} \\
\hline & & $\begin{array}{c}\text { Agreement } \\
\text { percentage } \\
\%\end{array}$ & $\begin{array}{l}\text { Arithmetic } \\
\text { mean }\end{array}$ & \begin{tabular}{|c|} 
Agreement \\
percentage \\
$\%$
\end{tabular} & $\begin{array}{l}\text { Arithmetic } \\
\text { mean }\end{array}$ & $\begin{array}{c}\text { Agreement } \\
\text { percentage } \\
\%\end{array}$ & $\begin{array}{l}\text { Arithmetic } \\
\text { mean }\end{array}$ & \\
\hline & First Dimension: Human Development and Invention & & & & & & & \\
\hline 1 & $\begin{array}{l}\text { There is a high level of training and knowledge to qualify } \\
\text { employees of youth and sports direction in Alexandria through } \\
\text { organizing training courses in: }\end{array}$ & & & & & & & \\
\hline $1 / 2$ & 1/2- Using modern technology for execution relevant works & 25 & 44.64 & 2 & 33.33 & 2 & 33.33 & 2.30 \\
\hline $1 / 3$ & 1/3- How to deal with others. & 30 & 53.57 & 4 & 66.67 & 4 & 66.67 & 1.84 \\
\hline $1 / 4$ & 1/4- Dealing with problems and suggesting solutions & 35 & 62.50 & 2 & 33.33 & 3 & 50.00 & $* 8.81$ \\
\hline $1 / 5$ & 1/5- Attending work setting changes & 27 & 48.21 & 2 & 33.33 & 2 & 33.33 & 3.86 \\
\hline 2 & $\begin{array}{l}\text { Having a data base about all the directorates employees and } \\
\text { considering the following: }\end{array}$ & & & & & & & \\
\hline $2 / 1$ & 2/1- Permanent updating & 26 & 46.43 & 3 & 50.00 & 4 & 66.67 & 4.29 \\
\hline $2 / 2$ & $\begin{array}{l}\text { 2/2- Changing to organizational plans from which youth and } \\
\text { sports directorate profits in achieving their purposes }\end{array}$ & 23 & 41.07 & 5 & 83.33 & 4 & 66.67 & $* 14.23$ \\
\hline 3 & $\begin{array}{l}\text { The directorate's employees accumulated experiences can be } \\
\text { used to help in creating a cultural climate suitable for } \\
\text { international changes }\end{array}$ & 39 & 69.64 & 4 & 66.67 & 4 & 66.67 & 0.09 \\
\hline 4 & $\begin{array}{l}\text { Enhancing employees awareness of the importance of joining } \\
\text { taking administrative decisions in youth and sports directorate }\end{array}$ & 22 & 39.29 & 5 & 83.33 & 5 & 83.33 & $* 18.84$ \\
\hline 5 & $\begin{array}{l}\text { Information technology of youth and sports directorate are } \\
\text { depended on as: }\end{array}$ & & & & & & & \\
\hline $5 / 1$ & 5/1- Investment resource & 22 & 39.29 & 2 & 33.33 & 2 & 33.33 & 0.67 \\
\hline $5 / 2$ & 5/2-Strategic goods & 42 & 75.00 & 2 & 33.33 & 1 & 16.67 & $* 43.33$ \\
\hline
\end{tabular}




\begin{tabular}{|c|c|c|c|c|c|c|c|c|}
\hline \multirow[b]{2}{*}{$\mathbf{s}$} & \multirow[b]{2}{*}{ Statements } & \multicolumn{2}{|c|}{$\begin{array}{c}\text { Executive Management } \\
\mathrm{N}=56 \\
\end{array}$} & \multicolumn{2}{|c|}{\begin{tabular}{|c|} 
Central Administration \\
$\mathrm{N}=6$ \\
\end{tabular}} & \multicolumn{2}{|c|}{\begin{tabular}{|c|} 
Senior Management \\
$\mathrm{N}=6$
\end{tabular}} & \multirow{2}{*}{$\begin{array}{c}\text { Crosal } \\
\text { Wallis } \\
\text { Test } \\
\text { "K2" }\end{array}$} \\
\hline & & $\begin{array}{c}\text { Agreement } \\
\text { percentage } \\
\%\end{array}$ & $\begin{array}{l}\text { Arithmetic } \\
\text { mean }\end{array}$ & $\begin{array}{c}\text { Agreement } \\
\text { percentage } \\
\%\end{array}$ & $\begin{array}{l}\text { Arithmetic } \\
\text { mean }\end{array}$ & $\begin{array}{c}\text { Agreement } \\
\text { percentage } \\
\%\end{array}$ & $\begin{array}{l}\text { Arithmetic } \\
\text { mean }\end{array}$ & \\
\hline $5 / 3$ & 5/3- National income source & 28 & 50.00 & 2 & 33.33 & 2 & 33.33 & 4.76 \\
\hline $5 / 4$ & $\begin{array}{l}\text { 5/4- Important field of attracting, selecting and appointing } \\
\text { employees }\end{array}$ & 24 & 42.86 & 3 & $\mathbf{5 0 . 0 0}$ & 3 & 50.00 & 0.71 \\
\hline 7 & $\begin{array}{l}\text { Achieving equity via enabling all employees to give their } \\
\text { opinions about the directorate through }\end{array}$ & & & & & & & \\
\hline $7 / 1$ & 7/1- Taking a part in decision making & 26 & 46.43 & 3 & 50.00 & 5 & 83.33 & $* 13.83$ \\
\hline $7 / 2$ & 7/2- Solving work problems & 22 & 39.29 & 4 & 66.67 & 4 & 66.67 & $* 8.69$ \\
\hline $7 / 4$ & 7/4 Distributing incentives and compensations & 20 & 35.71 & 5 & 83.33 & 5 & 83.33 & $* 22.41$ \\
\hline \multirow[t]{2}{*}{$7 / 5$} & 7/5 Applying award and punishment & 18 & 32.14 & 4 & 66.67 & 6 & 100.00 & $* 34.74$ \\
\hline & $\begin{array}{l}\text { Second Dimension: Infrastructure depending on } \\
\text { information technology and communication: }\end{array}$ & & & & & & & \\
\hline 8 & $\begin{array}{l}\text { 8/1 International information network of the directorate to } \\
\text { facilitate communication }\end{array}$ & & & & & & & \\
\hline $8 / 1$ & 8/2 Clear and declared website for correspondences & 22 & 39.29 & 5 & 83.33 & 5 & 83.33 & *18.84 \\
\hline $8 / 2$ & 8/3 Fax in all directorate's department & 12 & 21.43 & 2 & 33.33 & 2 & 33.33 & 3.22 \\
\hline $8 / 3$ & 8/4 Social media & 40 & 71.43 & 5 & 83.33 & 4 & 66.67 & 2.00 \\
\hline $8 / 4$ & $\begin{array}{l}\text { Information system center is available for all matters related to } \\
\text { youth and sports directorate internally and externally }\end{array}$ & 45 & 80.36 & 6 & 100.00 & 6 & 100.00 & 2.75 \\
\hline 9 & $\begin{array}{l}\text { Information and knowledge were published, prepared and } \\
\text { adapted with beneficiaries needs }\end{array}$ & 10 & 17.86 & $\mathbf{0}$ & $\mathbf{0 . 0 0}$ & $\mathbf{0}$ & $\mathbf{0 . 0 0}$ & *35.71 \\
\hline 10 & Youth and sports directorate has e-marketing unit & 30 & $\mathbf{5 3 . 5 7}$ & 3 & $\mathbf{5 0 . 0 0}$ & 3 & 50.00 & $\mathbf{0 . 1 7}$ \\
\hline 11 & $\begin{array}{l}\text { The directorate's employees deal with other authorities } \\
\text { electronically in all sports services and activities }\end{array}$ & 6 & 10.71 & $\mathbf{0}$ & $\mathbf{0 . 0 0}$ & $\mathbf{0}$ & $\mathbf{0 . 0 0}$ & $* 21.43$ \\
\hline
\end{tabular}




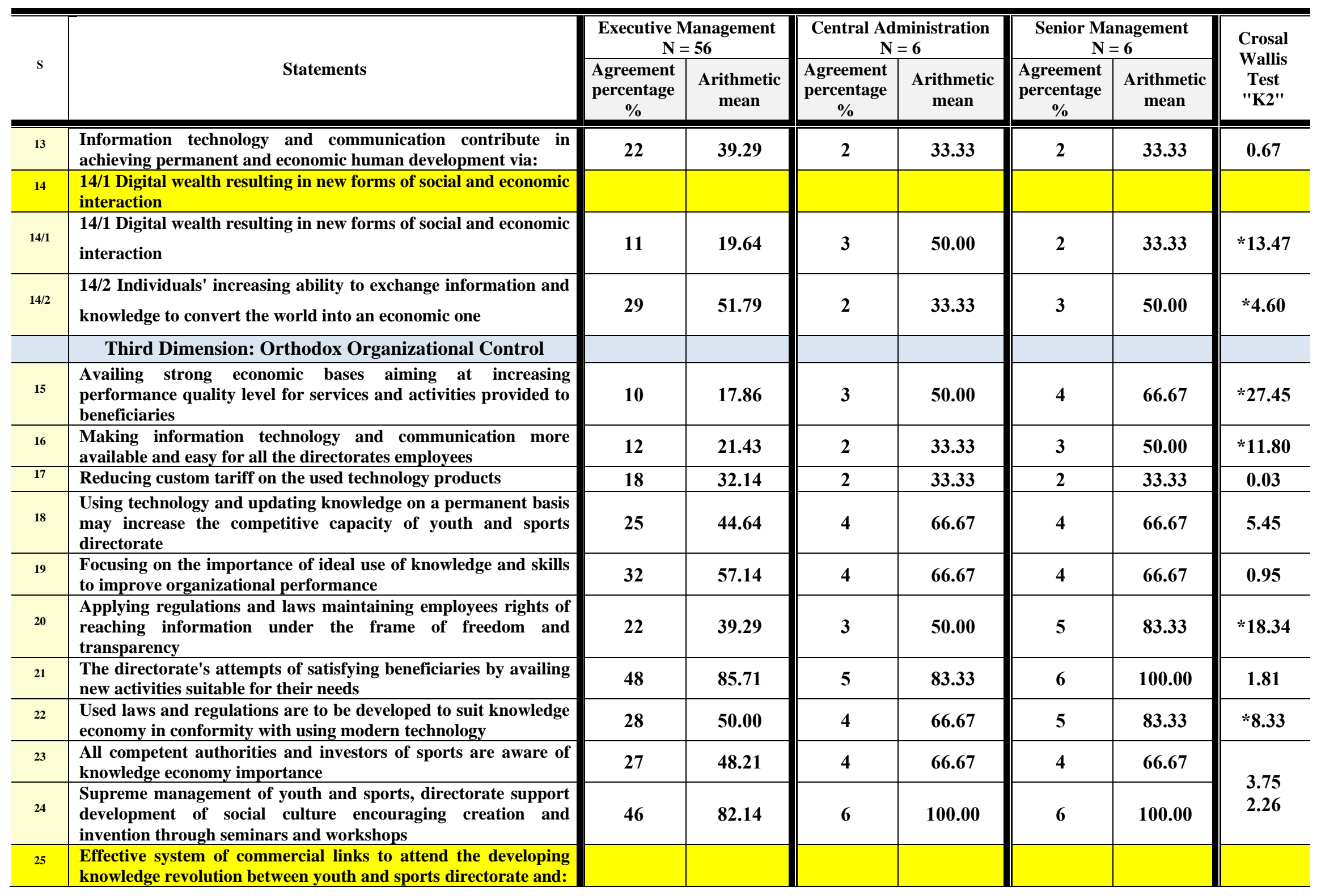




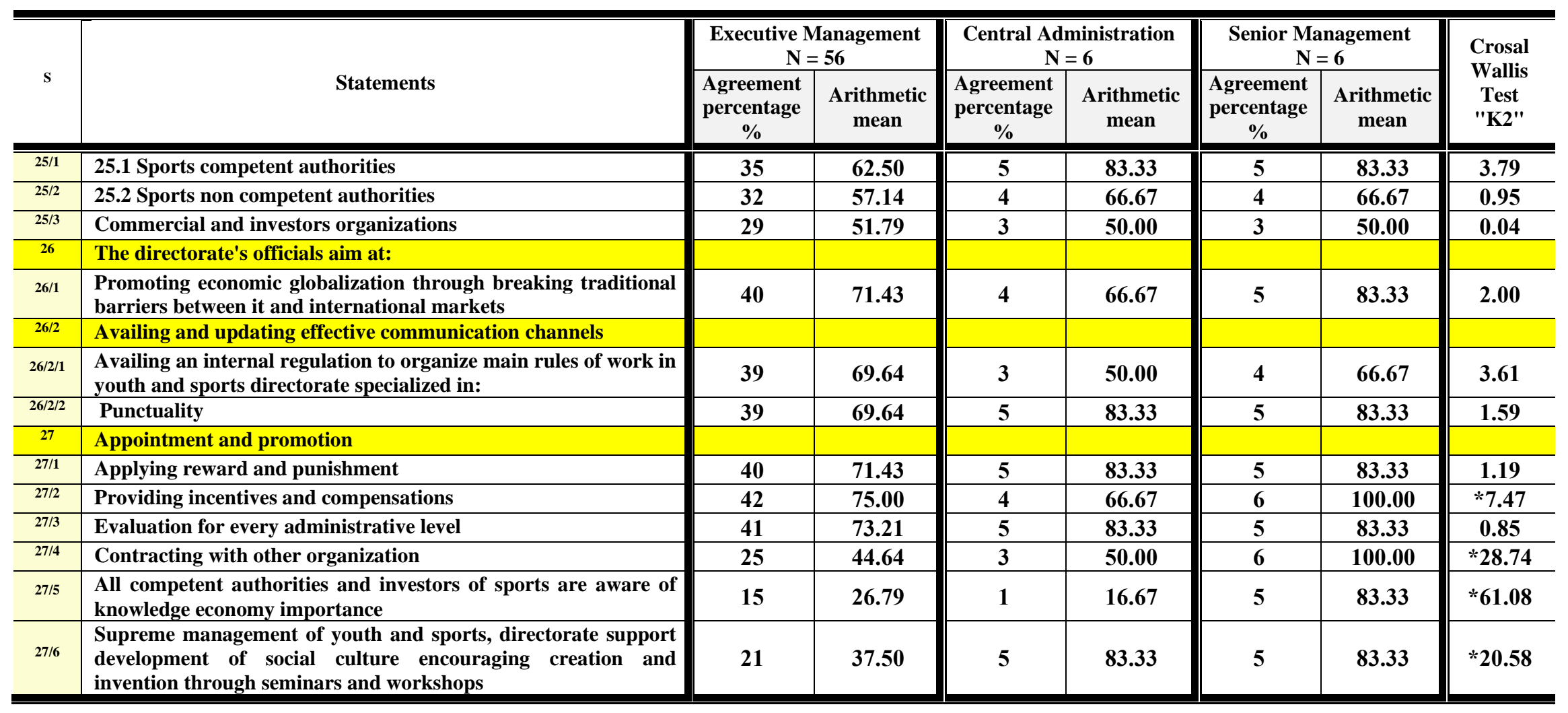

It is clear from table (5) of repetition, percentage and $\mathrm{K}^{2}$ for the three administrative level of the first factor: knowledge economy dimensions that there are statistical significant difference at level 0.05 as calculated $\mathrm{K}^{2}$ was higher than tabular $\mathrm{K}^{2}$ at level $0.05=5.99$ for phrases $(1 / 4,2 / 2,4,5 / 2,7 / 7,1 / 2,7 / 7,3 / 4,7 / 5,(1 / 8,9,11,12,15,16,20,27,22 / 2,27 / 4,27 / 5,27 / 6)$ and insignificant for the remaining factor statements. 


\section{Discussing the First Factor Results: Knowledge Economy Dimensions (Human Development and Invention - Technology Infrastructure - Orthodox Organizational Control)}

It is clear from table ( ) all research groups response direction to (yes) on statements $(1 / 1,1 / 3,3)$ in the first dimension as agreement percentages were $(53.57: 87.50 \%)(66.67: 83.33 \%)(66.67 \%)$ respectively subject to organizing training courses of administrating and organizing festivals and sports championships, how to deal with others, making use of accumulated experiences of the directorate's employees to help in creating culture climate suitable for international changes and statement number (4/1) of the second dimension ranged between $(80.36 \%)(100 \%)(100 \%)$ respectively related to the directorate's officials attempts to avail a social media for communications as a method of technology communication, statements $(19,21,24,25 / 25,1 / 2$, $26 / 26,1 / 2,27 / 1,27 / 2,2 / 3)$ in the third dimension and agreement percentage ranged between (57.14: 85.71\%) (66.67:100 \%) (66.67:100 \%) respectively which indicates the importance of the optional use of knowledge, skills and capacities to improve organizational performance, the directorate attempts to satisfy beneficiaries by availing new activities suitable for their needs, supreme management of youth and sports directorate support the development of social culture encouraging for invention and creation through seminars and workshops, an effective system of commercial links to attend the developing knowledge revolution between youth and sports directorate and sports competent and non competent authorities.

According to these results, study of Raid Ashoush (2008) (34) confirm that knowledge is a final factor of controlling economic resources and organizations' work, national authorities such as (European committee) compiled perfect indicators to measure some economic performance aspects depending on knowledge, statistics proved the relationship between investing in knowledge and economic performance quality, investment means constituting and updating human capital, quality of education, cultural nationalization and supporting services depending on knowledge as technology new uses play an important role or concerning corruption in governmental departments and business sector due to perfect accounting availed by, yet, application to public elections may have risks regarding non controlling competent parties.

But statements in which all research groups responses directed to (No) are $(1 / 1,2 / 5,5 / 1)$ in the first dimension as agreement percentage ranged between $(48.21: 39.29 \%)(33.33 \%)(33.33 \%)$ respectively on using modern technology in executing relevant works. Attending work environment changes depending on information technology as an investment resource, and statements

$(8 / 13$, $11,9,1)$ in the second dimension as agreement percentage ranged between 
$(10.71: 39.29 \%)(0.00: 33.33 \%)(0.00: 33.33 \%)$ on availing a clear and declared website for correspondences, availing information system center for all affairs related to youth and sports directorate internally and externally, availing on electronic marketing unit in youth and sports directorate, availing the budget needed for technology application in youth and sports directorate, and statement (17) of the third dimension whose percentage (44.64\%) $(33.33 \%)(33.33 \%)$ of reducing custom tariffs on the used technology products.

Results of study of Hamed Karim El Hedrawy (2010)(16) confirm that availing infrastructure on information technology and communication may avail a suitable economic environment called knowledge economy factors by international bank and to evaluate knowledge and its economy, some international organizations cooperate with some statistical organizations and departments to reach conclusions serving directing to measuring indicators perfectly.

These results agree with results of study of Duffy Jan (2000)(12) noted that Orthodox organizational control depends on strong economic bases able to avail all legal and political frames aiming at productivity and growth increase these policies, aiming at making information technology more available and easy and reducing custom tariff, include technology products and small and middle size organizations competitions.

Despite the agreement of high and middle management of response direction (yes) on statements $(7,4)$ in the first dimension and statement $(8 / 1)$ in the second dimension and statement $(15,18,23)$ in the third dimension with agreement percentage between $(66.67: 100 \%)$ we will find the executive management response in the direction (no) with agreement percentage (10.71: $46.43 \%)$ enhancing employees awareness of the importance of joining administrative decision making, in youth and sports directorate achieve equity through participation of all employees for giving their opinions in the directorate, availing strong economic bases aiming at increasing level of quality of performance for services and activities provided to beneficiaries, all competent authorities and investors in sports know the importance of knowledge economy.

Also results of study of Mohamed Abo El Shamat (2012) (24) confirms that knowledge economy need some main requirements for continuity and development including availing structure for communication and information technology, to create an information community, developing laws used to suit knowledge economy, establishing and developing human capital through availing a climate helping in knowledge by the state to be the most important productive element, all organizations and investors shall be aware of knowledge economy importance. 
The Second Factor Results: Permanent Human Development Indicators

Table (6)

\begin{tabular}{|c|c|c|c|c|c|c|c|c|}
\hline \multirow[b]{2}{*}{$\mathrm{s}$} & \multirow[b]{2}{*}{ Statements } & \multicolumn{2}{|c|}{$\begin{array}{l}\text { Executive Management } \\
\quad \mathrm{N}=56\end{array}$} & \multicolumn{2}{|c|}{$\begin{array}{l}\text { Central Administration } \\
\qquad N=6\end{array}$} & \multicolumn{2}{|c|}{$\begin{array}{l}\text { Senior Management } \\
\quad \mathrm{N}=6\end{array}$} & \multirow{2}{*}{$\begin{array}{c}\text { Crosal } \\
\text { Wallis Test } \\
\text { "K2" }\end{array}$} \\
\hline & & $\begin{array}{c}\text { Agreement } \\
\text { percentage } \\
\%\end{array}$ & $\begin{array}{l}\text { Arithmetic } \\
\text { mean }\end{array}$ & \begin{tabular}{|c|}
$\begin{array}{c}\text { Agreement } \\
\text { percentage } \\
\%\end{array}$ \\
\end{tabular} & $\begin{array}{c}\text { Agreement } \\
\text { percentage } \\
\%\end{array}$ & $\begin{array}{l}\text { Arithmetic } \\
\text { mean }\end{array}$ & $\begin{array}{c}\text { Agreement } \\
\text { percentage } \\
\%\end{array}$ & \\
\hline \multirow[t]{2}{*}{1} & (First Dimension: Enablement) & & & & & & & \\
\hline & $\begin{array}{l}\text { Youth and Sports Directorate shall avail work climate } \\
\text { suitable for enabling employees via: }\end{array}$ & & & & & & & \\
\hline $1 / 1$ & Having power necessary for executing required tasks & 43 & 76.79 & 3 & 50.00 & & 0.00 & *71.88 \\
\hline $1 / 2$ & Joining: & & & & & & & \\
\hline 1/2/1 & Compiling general objectives & 20 & 35.71 & 4 & 66.67 & 4 & 66.67 & $* 11.33$ \\
\hline $1 / 2 / 2$ & Identifying plans required to be executed & 18 & 32.14 & 4 & 66.67 & 4 & 66.67 & *14.41 \\
\hline $1 / 2 / 3$ & Taking administrative decisions & 19 & 33.93 & 3 & 50.00 & 5 & 83.33 & *22.78 \\
\hline $1 / 3$ & Giving opinions and creation and invention freedom & 36 & 64.29 & 5 & 83.33 & 5 & 83.33 & 3.14 \\
\hline $1 / 4$ & Solving problems and developing the directorate's work & 29 & 51.79 & 4 & 66.67 & 6 & 100.00 & *16.74 \\
\hline $1 / 5$ & Consolidation authority delegation & 24 & 42.86 & 2 & 33.33 & 4 & 66.67 & *12.38 \\
\hline $1 / 6$ & Formulating job description of his job & 44 & 78.57 & 6 & $\mathbf{1 0 0 . 0 0}$ & 5 & 83.33 & 2.90 \\
\hline 2 & $\begin{array}{l}\text { Transparency of decision making at all directorate's } \\
\text { administrative levels }\end{array}$ & 30 & 53.57 & 4 & 66.67 & 6 & 100.00 & $* 15.61$ \\
\hline 3 & $\begin{array}{l}\text { Enabling youth and sports directorate's employees } \\
\text { many advantages including: }\end{array}$ & & & & & & & \\
\hline 3/1 & 3/1- Advantages related to employee represented in: & & & & & & & \\
\hline 3/1/1/1 & Increasing work motivation & 17 & 30.36 & 4 & 66.67 & 5 & 83.33 & *24.41 \\
\hline $3 / 1 / 2$ & Developing its skills and advancing its performance & 20 & 35.71 & 5 & 83.33 & 4 & 66.67 & *18.86 \\
\hline 3/1/3 & Acquiring new knowledge & 22 & 39.29 & 3 & 50.00 & 5 & 83.33 & $* 18.34$ \\
\hline $3 / 1 / 4$ & Achieving occupational safety & 14 & 25.00 & 2 & 33.33 & 4 & 66.67 & *23.33 \\
\hline $3 / 1 / 5$ & Feeling the importance of his tasks & 16 & 28.57 & 3 & 50.00 & 5 & 83.33 & *28.22 \\
\hline $3 / 1 / 6$ & Achieving occupational satisfaction & 15 & 26.79 & 3 & 50.00 & 5 & 83.33 & *30.28 \\
\hline $3 / 1 / 7$ & Resisting work pressures & 25 & 44.64 & 3 & 50.00 & 3 & $\mathbf{5 0 . 0 0}$ & 0.40 \\
\hline 3/1/8 & Bearing responsibilities & 24 & 42.86 & 3 & 50.00 & 5 & 83.33 & *15.89 \\
\hline 3/1/9 & Increasing self-confidence & 26 & 46.43 & 2 & 33.33 & 4 & 66.67 & *11.56 \\
\hline $3 / 2$ & Advantages related to youth and sports directorate: & & & & & & & \\
\hline $3 / 2 / 1$ & Enhancing loyalty to sports and youth directorate & 34 & 60.71 & 4 & 66.67 & 5 & 83.33 & 3.91 \\
\hline $3 / 2 / 2$ & Increasing administrative creative efficiency & 25 & 44.64 & 3 & 50.00 & 4 & 66.67 & 4.91 \\
\hline $3 / 2 / 3$ & Executing programs of administrative work development & 29 & 51.79 & 3 & 50.00 & 5 & 83.33 & *11.40 \\
\hline
\end{tabular}




\begin{tabular}{|c|c|c|c|c|c|c|c|c|}
\hline \multirow[b]{2}{*}{$\mathrm{s}$} & \multirow[b]{2}{*}{ Statements } & \multicolumn{2}{|c|}{$\begin{array}{l}\text { Executive Management } \\
\qquad \mathrm{N}=56\end{array}$} & \multicolumn{2}{|c|}{$\begin{array}{l}\text { Central Administration } \\
\qquad \mathrm{N}=6\end{array}$} & \multicolumn{2}{|c|}{$\begin{array}{l}\text { Senior Management } \\
\quad \mathrm{N}=6\end{array}$} & \multirow{2}{*}{$\begin{array}{l}\text { Crosal } \\
\text { Wallis Test } \\
\text { "K2" }\end{array}$} \\
\hline & & $\begin{array}{c}\text { Agreement } \\
\text { percentage } \\
\%\end{array}$ & $\begin{array}{l}\text { Arithmetic } \\
\text { mean }\end{array}$ & $\begin{array}{c}\text { Agreement } \\
\text { percentage } \\
\%\end{array}$ & $\begin{array}{l}\text { Agreement } \\
\text { percentage } \\
\%\end{array}$ & $\begin{array}{l}\text { Arithmetic } \\
\text { mean }\end{array}$ & $\begin{array}{c}\text { Agreement } \\
\text { percentage } \\
\%\end{array}$ & \\
\hline 3/2/4 & $\begin{array}{l}\text { Increasing communication efficiency and improving employee } \\
\text { interrelationships }\end{array}$ & 28 & 50.00 & 4 & 66.67 & 5 & 83.33 & $* 8.33$ \\
\hline $3 / 2 / 5$ & Increasing cooperation of solving problems & 19 & 33.93 & 3 & 50.00 & 4 & 66.67 & $* 10.68$ \\
\hline 3/2/6 & Improving types of services provided to beneficiaries & 29 & 51.79 & 5 & 83.33 & 5 & 83.33 & $* 9.11$ \\
\hline \multirow[t]{2}{*}{$3 / 2 / 7$} & Achieving competitive advantage & 14 & 25.00 & 4 & 66.67 & 6 & 100.00 & *44.20 \\
\hline & Second Dimension: Occupational Safety & & & & & & & \\
\hline 4 & $\begin{array}{l}\text { Youth and Sports Directorate shall provide employees with all } \\
\text { needs and resources satisfying their needs to achieve a suitable } \\
\text { financial level including: }\end{array}$ & 19 & 33.93 & 3 & 50.00 & 3 & 50.00 & 3.86 \\
\hline $4 / 1$ & Availing good life & 14 & 25.00 & 2 & 33.33 & 4 & 66.67 & *23.33 \\
\hline $4 / 2$ & Health care & 17 & 30.36 & 3 & 50.00 & 4 & 66.67 & *13.48 \\
\hline $4 / 3$ & $\begin{array}{l}\text { Paying salaries meeting minimum level of welfare for every } \\
\text { employee }\end{array}$ & 16 & 28.57 & 4 & 66.67 & 5 & 83.33 & $* 26.48$ \\
\hline \multirow[t]{3}{*}{$4 / 4$} & 4/4- Social and moral needs & 18 & 32.14 & 4 & 66.67 & 4 & 66.67 & $* 14.41$ \\
\hline & 4/5- Spiritual and psychological needs & & & & & & & \\
\hline & The directorate's employees feel occupational stability through: & & & & & & & \\
\hline $5 / 1$ & Availing climate suitable for work & 24 & 42.86 & 3 & 50.00 & 3 & 50.00 & 0.71 \\
\hline $5 / 2$ & Mutual confidence between all parties & 25 & 44.64 & 2 & 33.33 & 4 & 66.67 & $* 11.92$ \\
\hline 5/3 & Applying award and punishment justly & 22 & 39.29 & 4 & 66.67 & 5 & 83.33 & $* 15.68$ \\
\hline $5 / 4$ & Loyalty to organization and pride & 20 & 35.71 & 2 & 33.33 & 5 & 83.33 & *31.32 \\
\hline $5 / 5$ & $\begin{array}{l}\text { Employees important feeling and creative participation in } \\
\text { achieving the general objectives }\end{array}$ & 21 & 37.50 & 4 & 66.67 & 6 & 100.00 & $* 28.74$ \\
\hline $5 / 6$ & There is an occupational safety system for employee & 39 & 69.64 & 5 & 83.33 & 5 & 83.33 & 1.59 \\
\hline $5 / 7$ & Encouraging invention and creation freedom & 26 & 46.43 & 5 & 83.33 & 5 & 83.33 & $* 12.78$ \\
\hline \multirow[t]{2}{*}{$5 / 8$} & $\begin{array}{l}\text { Maintaining employees rights and obligations according to } \\
\text { work regulations and laws }\end{array}$ & 37 & 66.07 & 5 & 83.33 & 6 & 100.00 & *6.92 \\
\hline & Third Dimension: Justice and Equity & & & & & & & \\
\hline 6 & $\begin{array}{l}\text { Putting all on an equal footing before law and applying law } \\
\text { efficiently }\end{array}$ & 17 & 30.36 & 3 & $\mathbf{5 0 . 0 0}$ & 5 & 83.33 & *26.29 \\
\hline 7 & $\begin{array}{l}\text { Applying equal opportunities to all employees of sports and } \\
\text { youth directorate when distributing: }\end{array}$ & & & & & & & \\
\hline $7 / 1$ & Financial and moral incentives & 14 & 25.00 & 4 & 66.67 & 4 & 66.67 & $* 21.93$ \\
\hline $7 / 2$ & Potentials available in work & 12 & 21.43 & 3 & 50.00 & 5 & 83.33 & $* 37.22$ \\
\hline $7 / 3$ & Burdens or tasks to be executed & 17 & 30.36 & 3 & 50.00 & 4 & 66.67 & *13.48 \\
\hline 8 & Applying award and punishment & 11 & 19.64 & 4 & 66.67 & 5 & 83.33 & *38.58 \\
\hline 9 & Considering individual differences between employees of youth & 10 & 17.86 & 4 & 66.67 & 3 & 50.00 & $* 27.45$ \\
\hline
\end{tabular}




\begin{tabular}{|c|c|c|c|c|c|c|c|c|}
\hline \multirow[b]{2}{*}{$\mathrm{s}$} & \multirow[b]{2}{*}{ Statements } & \multicolumn{2}{|c|}{$\begin{array}{l}\text { Executive Management } \\
\qquad \mathrm{N}=56\end{array}$} & \multicolumn{2}{|c|}{$\begin{array}{l}\text { Central Administration } \\
\qquad \mathbf{N}=6 \\
\end{array}$} & \multicolumn{2}{|c|}{$\begin{array}{c}\text { Senior Management } \\
\quad \mathrm{N}=6 \\
\end{array}$} & \multirow{2}{*}{$\begin{array}{c}\text { Crosal } \\
\text { Wallis Test } \\
\text { "K2" }\end{array}$} \\
\hline & & $\begin{array}{c}\text { Agreement } \\
\text { percentage } \\
\%\end{array}$ & $\begin{array}{l}\text { Arithmetic } \\
\text { mean }\end{array}$ & $\begin{array}{l}\text { Agreement } \\
\text { percentage } \\
\%\end{array}$ & $\begin{array}{l}\text { Agreement } \\
\text { percentage } \\
\%\end{array}$ & $\begin{array}{l}\text { Arithmetic } \\
\text { mean }\end{array}$ & $\begin{array}{c}\text { Agreement } \\
\text { percentage } \\
\%\end{array}$ & \\
\hline & $\begin{array}{l}\text { and sports directorate and evaluating their potentials } \\
\text { according to qualifications }\end{array}$ & & & & & & & \\
\hline 10 & $\begin{array}{l}\text { The manager shall accept employees' criticism in a positive } \\
\text { manner }\end{array}$ & 12 & 21.43 & 5 & 83.33 & 6 & 100.00 & $* 50.22$ \\
\hline 11 & $\begin{array}{l}\text { Supporting all employees and rectifying mistakes to avoid } \\
\text { administrative problems aggravation }\end{array}$ & 15 & 26.79 & 3 & $\mathbf{5 0 . 0 0}$ & 5 & 83.33 & $* 30.28$ \\
\hline \multirow[t]{2}{*}{12} & $\begin{array}{l}\text { Creating an optional system for incentives and compensations } \\
\text { suitable for responsibilities and tasks assigned be employees. }\end{array}$ & 22 & 39.29 & 3 & $\mathbf{5 0 . 0 0}$ & 4 & 66.67 & $* 7.32$ \\
\hline & $\begin{array}{c}\text { Fourth Dimension: Cooperation } \\
\end{array}$ & & & & & & & \\
\hline 13 & $\begin{array}{l}\text { Common subject for all employees cooperate to achieve to feel } \\
\text { loyal to the directorate }\end{array}$ & 43 & 76.79 & 5 & 83.33 & 5 & 83.33 & 0.35 \\
\hline 14 & $\begin{array}{l}\text { Departments' heads cooperate with employees to achieve their } \\
\text { tasks }\end{array}$ & 9 & 16.07 & 6 & 100.00 & 5 & 83.33 & *59.41 \\
\hline 15 & $\begin{array}{l}\text { Enhancing cooperation between youth and sports directorate } \\
\text { and other sports organizations to establish knowledge research } \\
\text { and development center }\end{array}$ & 8 & 14.29 & 2 & 33.33 & 3 & 50.00 & *19.63 \\
\hline 16 & $\begin{array}{l}\text { Availing social organization affecting fatal decision making in } \\
\text { sports and youth directorate via: }\end{array}$ & & & & & & & \\
\hline $16 / 1$ & $\begin{array}{l}\text { Distributing knowledge and exchanging experiences between } \\
\text { employees through seminars }\end{array}$ & 24 & 42.86 & 4 & 66.67 & 3 & 50.00 & 5.61 \\
\hline $16 / 2$ & $\begin{array}{l}\text { Developing exchanged respect between superiors and inferiors } \\
\text { in work }\end{array}$ & 40 & 71.43 & 5 & 83.33 & 3 & 50.00 & *8.36 \\
\hline $16 / 3$ & - Establishing exchanged organizational culture & 36 & 64.29 & 3 & 50.00 & 3 & 50.00 & 2.48 \\
\hline $16 / 4$ & $\begin{array}{l}\text { Availing opportunities for interaction and communication with } \\
\text { employees on all administrative levels }\end{array}$ & 28 & $\mathbf{5 0 . 0 0}$ & 4 & 66.67 & 4 & 66.67 & 3.03 \\
\hline $16 / 5$ & $\begin{array}{l}\text { The management shall enhance brotherhood and cooperation } \\
\text { between employees }\end{array}$ & 29 & 51.79 & 4 & 66.67 & 5 & 83.33 & $* 7.41$ \\
\hline
\end{tabular}




\section{Discussing the second factor: permanent human development indicators}

From table (6) it is clear that all the research groups agreed in response direction by yes about statements $(1 / 1,3 / 1,4 / 6)$ in the first dimension and statement (3/2) in the second dimension and statement (5/6) in the third dimension and statements $(13,16 / 5)$ in the fourth dimension ranged between (51.79: $78.57 \%)(66.67: 100 \%)(83.33: 100 \%)$ respectively which is related to opinion and freedom of creation and invention, solving problems and developing the directorate's work, formulating occupational description of his job developing his skills and performance level, there is a common objective for all employees trying to achieve which make them feel legal to the directorate, management's attempts to enhancing brotherhood and cooperation between employees.

These results agree with recommendation of study of Ashraf Eid Abdel Aziz Abdalla (2017)(9) and Asmaa Ahmed Abdel Moneim Mohamed Nasr (2015) (8) of the importance of enabling employees as a work priority because enabling is the basis of creating successful decisions and disposal of different situation and, in turn; affect their achievement motivation, reviewing compensation system and securing incentives related to performance levels and enabling employees participation in decision making, enhancing employees trust of their abilities to control their work and create in, holding seminars and courses enhancing dialogue inside clubs and extending bridges of thinking and creation for employees.

Study of Adel Hamdy Taha Mahmoud (2011) (4) recommended the importance of having a program for administrative development organization workshops supervised by specialists in the field of psychology, sociology and sports administration employees, training leaderships on democratic behavior and non centralism in work and how to support group work in conformity with group coherence.

By looking into all the third dimensions statements, we will find responses of executive administration with direction (No) are all statements of the third dimension and the middle administration responses direction to (No) except for they are neutral for some statements such as $(7,6 / 11,2)$ while the supreme administrative response was (yes) with agreement percentage ranged (66.67:100 \%) of applying equal opportunities between employees of youth and sports directorate when distributing financial and moral incentives, potentials available in work place, burdens and tasks required to be achieved, applying reward and punishment, considering individual differences between employees of youth and sports directorate and evaluating their capacities according 
to their qualifications, an optimal system for incentives and compensations suitable for employees responsibilities.

Study of Bergas Faleh (2010) (10) of the most important results are that enabling is one of the most important factors and a main and important function is the indicator of any administrative work success, also selecting employees need efficiency norms and that enabling may focus on availing environment resources in the competitive school setting which needs speed, efficiency, creation and committing to services.

Studies of results of Bolsag Reyad (2013) (11) added that the used human development method confirms the importance of enabling all community's individuals to expand their human capacities scope and using the same as it should be.

Libowitz (2004) (22) clarifies that the most important factors guaranteeing the success of knowledge administrative programs shall be developing mental capital including supporting invention.

Also some statements $(3 / 1 / 5,5 / 4)$ received supreme administration response by yes at percentage $(66.67: 83.33 \%)$, but the response of executive and middle administration was (no) with agreement percentage between (25.00:36 \%) on achieving employees functional safety in youth and sports directorate, loyalty to the organization and pride.

Also results of study of Abdo Mahmoud Abdel Halim Attia (2008) (3) confirmed that availability of a suitable degree of enabling such as self efficiency may affect satisfaction of employees of youth and sports of South Upper Egypt.

Despite the agreement of middle and supreme administration in the direction of (yes) for statements $(1 / 2 / 1,1 / 2 / 2,3 / 1 / 1,3 / 2 / 7,4)$ at agreement percentage between $(66.67: 100 \%)$ we will find in executive administration, the prevailing direction (no) had an agreement percentage between (25.00: $46.43 \%$ ) on employees' participation in compiling general objectives, determining plans required to be executed, increasing work motivation and achieving the competitive advantage.

According to these results of study of Ashraf Hany Herz, Taghrid Said Hassan (2012) (9) confirm that investing in human capital in such organizations became important due to its role of providing high quality services, and to find an organizational structure specially in these organizations agree with employees trends and motivate their creative capacities in the direction of providing a distinctive advantages, and at the same time achieve objectives and aspirations of these organizations owners for achieving profit and stability under highly competitive climates.

This agree with what was referred to by Martin Morgan (2009) (23) of that enabling has no direct effects on performance through increasing 
the ability to internal motivation and ability to performance and development.

Also results of study of Amr Yassin Ahmed Sadek (2005) (6) resulted in a relationship between achievement motivation and level of aspiration for employees in youth center in Fayoum, also there is a relationship between achievement motivation and the organizational structure of youth center employees.

Also results of study of Abdel Rahman Ben Antr and Abdel Razek Hemidi (2010) (2) confirmed that knowledge economy is a resultant of interaction between directions of advancement of information technology and communications and economic organization and that information technology became one of the most important modern economic organization power.

\section{Conclusions}

- Organizing training courses of managing and organizing festivals and sports championship and how to deal with others.

- Making use of accumulated experiences for employees of the directorate to help in creating a cultural climate suitable for international changes.

- Not using modern technology in executing relevant works.

- Un attending work environmental changes and information technology can't be use as a investment resource.

- Having no website to be used for correspondences.

- No information system center for what is related to youth and sports directorate internally and externally.

- Lack of e-marketing unit in youth and sports directorate.

- Technology application budget of youth and sports directorate is not enough.

- No equal opportunity is applied to employees of youth and sports directorate when distributing financial and moral incentives, work potentials, burdens or tasks required to be achieved, applying reward and punishment.

- Ignoring individual differences between employees of youth and sports directorate and achieving their potentials depending on their qualifications.

- Lack of optimal system of incentives and compensations suitable for employees' responsibilities and tasks. 


\section{Recommendations}

Under reached conclusions, some recommendations were made as follows:

\section{a. Recommendations directed to Ministry of Youth and Sports}

- Focusing on organizing conferences and workshops to apply knowledge economy in youth and sports directorates.

- Focusing on providing studies and researches related to knowledge and knowledge economy in sports organizations.

- Availing finance necessary to support youth and sports directorate to achieve knowledge economy requirements and trying to apply the same in sports organizations.

- Providing an integrated strategic plan to develop the knowledge fact including understanding weak and strong points and trying to develop policies and investments suitable for directions and objectives and making use of local, Arab and international experiences and supporting all relevant sectors in conformity with optimal use of available resources.

\section{b. Recommendations directed to Youth and Sports Directorate in} Alexandria

- Availing the suitable knowledge environment to encourage creation and invention among the directorate's employees and promoting partnership and knowledge integration to convert to electronic organization.

- Availing an infrastructure suitable for modern information technology in conformity with electronic and digital deal.

- Enhancing cooperation between youth and sports directorate and sports organizations to focus on establishing centers of research and knowledge development to qualify the directorate's human resources in all fields. 


\section{References \\ First: The references}

1- Abdulmutallab Abdel Hamid (2011) : Knowledge Economy, University House.

2- Abdul Rahman bin Antar Abdul Razzaq Knowledge Economy and Enhancing the Competitiveness of the Foundation, published a fourth international conference on competition and competitive strategies for industrial establishments outside the hydrocarbons sector in the Arab countries.

3- Abdo Mahmoud Abdel Halim (2008): Effect of Empowering Workers on Satisfaction, Applied Study on Workers in Youth and Sports Administrations in Southern Upper Egypt, Unpublished MA Thesis, Journal of the Faculty of Education for Scientific Research, Alexandria University, No. 3.

4- Adel Hamdy Taha (2011): Leadership Behavior of Presidents and their Relation to Some Motivational and Emotional Aspects of Workers in the Field of Minia Governorate, Unpublished MA Thesis Journal of the Faculty of Education for Scientific Research, Minia University, Issue 5.

5- Ahmed Abdullah Al-Zayabat (2007): The Role of the Knowledge Economy in Preparing Human Resources to Meet the Requirements of Sustainable Development in Jordan, Dissertation, Unpublished, Yarmouk University, Jordan.

6- Amr Yassin Ahmed (2005): Organizational climate and its relation to the motivation for achievement and the level of ambition, applied study on workers in youth centers in Fayoum Governorate, unpublished MA study. Journal of the Faculty of Commerce for Scientific Research, Alexandria University.

7- Asmaa Ahmed Abdel Moneim Mohamed Nasr (2015): The relationship of empowerment to motivation of achievement for the employees of the management of sports activity in some sports clubs in Alexandria, unpublished master thesis, Faculty of Physical Education for Girls, University of Alexandria.

8- Ashraf Abdul Aziz Abdullah (2017): Administrative Empowerment and its Relationship to Participate in Decision Making in Youth 
Centers in Gharbia Governorate, unpublished Master Thesis, Faculty of Physical Education for Girls, Alexandria University.

9- Ashraf Hany Harz, Taghreed Saeed Hassan (2012): Investment of Human Capital and its Impact on Achieving the Total Quality of Sports Institutions Journal of Administration and Economics, University of Mustansiriya Issue 114 (341-359).

10- Berjis Falih Al-Hajri (2010): The Relationship between Empowerment of Managers and the Performance of Employees, An Applied Study of the Management and Teaching Body in the Intermediate Schools of Kuwait, Unpublished MA Thesis Journal of the Faculty of Commerce for Scientific Research, Alexandria University.

11- Pulsage Riyad (2013) Sustainable Human Development and Knowledge Economy in the Arab Countries, unpublished Master Thesis, Faculty of Economic Sciences and Facilitation Sciences, Farhat Abbas Steef University, Algeria.

12- Duffy, Jan (2000): Something funny is happening on the way to knowledge management. Information management journal Oct. Vol. 34 Issue, 4.3

13-Diane-Gabrielle Tremblay,Ne $\mathrm{w}$ types of careers in the knowledge economy? Networks and boundaryless gobs as a career strategy in the ic $\mathrm{t}$ and multimedi sector,research note no $2 \mathrm{a}$, Canada research chair on the cocio-organtzatonal challenges of the knowledge economy. 2003

14- Duraid Kamel Shabib (2010): The impact of knowledge economy elements on the efficiency of financial markets.

15- Ghaleb Awad Al-Rifai (2004): "An Academic Perspective on Knowledge Management", Journal of the Association, Special Issue, Volume IV, Nos. 3 and 4, November.

16- Hamed Karim Al Hadrawi: Impact of Information Technology Strategy in Knowledge Economy, unpublished $\mathrm{PhD}$ thesis, Mustansiriya University, Iraq 2010.

17- Hassna Mahmoud Mahjoub (2006): The Road to Knowledge Society, Series of Issues, Cairo, Center Al-Ahram for Political and Strategic Studies, No. 24, December 2006, p. 
18- Hussein Ahmed Dakhil Al Sarhan (without)Sustainable Human Development and Building a Knowledge Society: Ahl al-Bayt Magazine, No. 16

19- Hackett Brain, Beyond K: New ways to work and to work and learn, the conference Board, 2003

20- Jillinda, J., et al "applying corporate knowledge management practices in higher education, EducaseRuarterly, no: 4, 2001

21- Khalid Al-Mahdi Najem Mohammed (2012): Human Capital as an Engine for Economic Growth and Sustainable Development in the Libyan Economy, unpublished Master Thesis, Faculty of Economics, Benghazi University.

22- Liebowitz ,j \& Suen .C, Developing knowledge management metrics for measuring intellectual capital, information systems and operations research ,v 38 ,n2 2004.

23- Martin Morgan (2009): the psychological impact of the empowerment of employees on job performance.

24- Mohammed Abu Shammat (2012):Trends of the Knowledge Economy in the Arab Countries, "Damascus University Journal of Economic and Legal Sciences, No. 1, vol. 28, p. 598, 599.

25- Mohamed Sayed Gomaa (2009): Education Development and its Role in the Knowledge Economy, 1st International Conference on eLearning - Learning Industry for the Future, Riyadh.

26- Mohammed Khadri (2004): Requirements for the Transition to a Knowledge Economy, published research, the fourth scientific conference Knowledge Management in the Arab World, Jordan Zaytooniya University, Faculty of Economics and Administrative Sciences.

27- Medhat Mohammed Abu El-Nasr (2009): Impediments of strategic planning and thinking, first edition, Arab Group for Training and Publishing.

28- Medhat Mohammed Kazem Qureshi (2007): Economic development (objective theories and policies), Amman, Dar Wael for publication and distribution, i 1. 
29- Marwa Mahmoud Omar (2005): Investment in Education and its Impact on Economic Growth (Applied Study Compared to a Special Reference to Egypt) ", Master Thesis, Helwan University, 2005

30- Marwa Farghli Jaber Farghali (2015) Proposed strategy for knowledge management for the development of knowledge economy Faculty of Physical Education Girls Alexandria University.

31- Najm Aboud Star Knowledge Management Concepts, Strategies and Processes, First Edition, Al-Warraq Publishing and Distribution, Jordan, 2005, 2008.

32- Naim Ibrahim Al-Zaher (2009): Knowledge Management, Amman, The World of Modern Books for Publishing and Distrib.

33- Pulsage Riyad (2013) Sustainable Human Development and Knowledge Economy in the Arab Countries, unpublished Master Thesis, Faculty of Economic Sciences and Facilitation Sciences, Farhat Abbas Steef University, Algeria.

34- Riad Ashoush, Magdi Noiri, Ben El-Barasad, (2008), Al-Rashed, unpublished Master Thesis, Faculty of Economic Sciences and AlTayseer University, Mohammed Khaydar University.

35- Reda Ibrahim Almiljugi (2010): Knowledge and Organizational Education Department, the entrance of the university educated in the knowledge society, the College of Education Banha.

36- Sayed Al-Bawab (2001) The Scientific Revolution of Contemporary Technology (The Third Industrial Revolution) what is its impact, its effects? (Al-Bayan for Printing and Publishing, Cairo,

37- Said Khudair Abbas Al-Rahimi (2005) The Knowledge Economy The Basis of the Economic and Social Development in the Arab Countries, Research published Journal of the University of Babylon for Pure and Applied Sciences Volume 19.

38- Saad Mohammad (2016): Human Development as a Standard for the Achievement of the Knowledge Economy in Algeria by reference to the Knowledge Index (2000-2010) "Algeria Telecom Case Study Ben Khaldoun Tiaret University.

39- Saih Bouzid (2013): The Role of Good Governance in Achieving Sustainable Development, University of Abu Bakr Belqayd, Tlemcen, Faculty of Economic Sciences and Facilitation Sciences, PhD Thesis, unpublished. 
40- United Nations Educational, Scientific and Cultural Organization (UNESCO): World Report (From the Information Society to the Knowledge Society): WWW.UNESCO.ORG/SHS.

41-Walter w. powell and kaisa snellzen, the knowledge economy,Downloaded, from arjournals.annualreviews.org by Stanford univ.robert crown law lib,2004

\section{Secant: websites}

42- https://omran.dohainstitute.org/ar/issue003/Pageas/art09.aspx (

43-www.worldbank.org/kam,Knowledge Assessment Methodology 2012 44-www.madarik.net/mag2/10.htm:hhh// 